\title{
ROLE OF QUALITY MANAGEMENT SYSTEM (QMS) ON THE PERFORMANCE OF TEACHER IN N 2 JEMBER
}

\author{
Agus Dedi Mustofa ${ }^{1}$ \\ Suwignyo Widagdo ${ }^{2}$ \\ Muhaimin Dimyati ${ }^{3}$ \\ Higher Education of Economic Mandala \\ e-mail: august.day84@gmail.com
}

\begin{abstract}
This research is aimed at identifying and analyzing the roles of Quality Management System (QMS) towards the productive teachers' performance of SMKN 2 Jember. The hypothesis of this research says Quality Management System (QMS) is partially significant effect on performance. The population of the research is productive teachers of SMKN 2 Jember. This research uses survey technique for sampling taken as a whole from the total population of productive teachers of SMKN 2 Jember. The samples of the population are 50 respondents of productive teachers of SMKN 2 Jember. The methods of data collection of this research are observation, interviews, questionnaires and documentation. The implications of research findings may contribute to the development of academic sciences and practitioners. The result of this research is to improve the productive teachers' performance which is consistent with the concept of human resources and the aspects of the Quality Management System towards productive teachers' performance which has partially significant effect on their performance.
\end{abstract}

Keywords: QMS and leadership

\section{INTRODUCTION}

As international quality standards, the implementation of a Quality Management System (QMS) ISO 9001: 2008 consistently will improve school quality and efficiency in the management of school resources. The Schools that implement this system will get more value and a better image in international community as a quality school. This term can increase the capability of school to provoke their public interest to manage their children to enter the school.

Vocational School (SMK) that already has ISO 9001: 2008 has the advantage that the application of ISO 9001: 2008 will be periodically audited by ISO certification institution at the beginning of the certification and once a surveillance visit year. The presence of a third party of an ISO certification institution that would encourage schools to implement and maintain ISO 9001: 2008 effectively as management standard that has been selected. This can be evaluated towards the documentations, workflow, communication, job descriptions, and standard operating procedures (SOP), which have been managed well so that all the elements of school organization can understand their respective duties.

International Standard Organization (ISO) 9001: 2008 is an evolving system of quality inspection systems, quality control, 
and then developed into an integrated quality assurance system, in Indonesia commonly called the Quality Management System (Sugeng, 2009). The quality management system refers to what is done by the agency in managing its processes or activities of the institution, so that the products or services meet the goals set. ISO 9001: 2008 does not guarantee the quality of goods and services the agency produced. ISO certificate simply states that a quality process and be consistently implemented at the agency.

In practice, the implementation of ISO 9001: 2008 in SMKN 2 Jember is not optimal in fulfilling the policy of the Directorate General of Primary and Secondary Education (Directorate General of Primary and Secondary Education) as well and increasing the school quality in the society. Since the cost for ISO certification itself is very expensive, it has not been matched with a maximum performance of each element of the school organization to implement a quality management system standardized ISO 9001: 2008.

Based on the phenomenon that has been described above, this research discusses the role of the Quality Management System (QMS) on productive teachers' performance in SMKN 2 Jember.

Based on the above background of the research, we can identify the purpose of this research that is to determine and analyze the role of the Quality Management System (QMS) on productive teachers' performance.

Based on the background and purpose of the research, the researcher limited the problem of this research on Quality Management System which refers to the guiding principle of ISO 9001: 2008 version 2007 which has been implemented in SMKN 2 Jember.

\section{RESEARCH METHODS}

The research was conducted at SMK 2 Jember located at Jl. Tawangmangu No. 59 Jember. The research was conducted in December 2016.

The subjects of this research were teachers SMKN 2 Jember. Total population of vocational teachers / productive at SMKN 2 Jember is 50 teachers who teach in their respective expertise program. This research uses the technique of taking the entire population of vocational/productive teachers at SMK Negeri 2 Jember.

The sampling technique uses sampling techniques saturated, i.e. sampling technique when all members of the population used as a sample (Sugiono (2011: 43).

This type of research is the study of causality. According to Ferdinand (2006), the study of causality is research to seek clarity and shape causality (cause-effect) between some concepts and some variable or multiple strategies developed in management.

The data sources used in this study are:

a. primary data obtained directly from respondents to the questionnaires

b. secondary data obtained indirectly from resources which is not done by the researchers. The secondary data sources are in the form of evidence of writing (documentation), reports from researchers and productive teachers of SMK 2 Jember related to the research.

The variables analyzed in this research are classified into two types as follows:

a. Independent variables: QMS

b. Dependent variables: productive teachers' performance

\section{RESULT ANALYSIS}

To determine the effect of independent variables on the dependent 
variable, the researcher partially used t-test, where this test comparing the t-test with a ttable results of tests on each variable quality management system performance.

\begin{tabular}{|l|c|c|c|}
\hline \multicolumn{1}{|c|}{ Variable } & t-count & t-table & Sig. \\
\hline $\begin{array}{l}\text { Quality } \\
\text { Management } \\
\text { System (X) }\end{array}$ & 4,084 & 2,013 & 0,000 \\
\hline
\end{tabular}

\section{Table 4:15 t-Test Results}

Based on the table above the value of t-test variable quality management system is at 4.084 with a probability value of 0.000 , while the t-table value amounted to 2,013 (Appendix 11), so that $\mathrm{t}$ count $>\mathrm{t}$-table $(4.084>2.013)$. This indicates that the variable quality management system partially have a significant effect on productive teachers' performance.

\section{INTERPRETATION}

Based on the analysis above shows that the influence of the Quality Management System (QMS) on teacher performance SMKN 2 Jember. According to the table above is t-count value of the quality management system variable is equal to 4.084 with a probability value of 0.000 , while the t-table value amounted to 2,013 (Appendix 11), so that $\mathrm{t}$ count $>\mathrm{t}$-table $(4.084>2.013)$. This indicates that the variable quality management system partially have a significant influence on performance.

The results are consistent with the hypothesis of the study, which says "Quality Management System (QMS) partially affect the productive teachers' performance". This proves that the QMS can support teachers as an important part of an educational institution to improve simultaneously the quality of focusing on the process and customers who demand the teachers also understand the requirements of ISO 9001: 2008 in setting and continuous process improvement.

In general, it can be stated that QMS of SMKN 2 Jember state official teachers have a high level. It can be confirmed by the results of the research which says that state official productive teachers of SMKN 2 Jember are able to collaborate with their partners.

The number of 22 respondents (44\%) stated strongly agree with this statement item, 22 respondents (44\%) agreed and only two respondents (4\%) stated strongly disagree. QMS mean is 4.09. This mean concludes that state official productive teachers are able to collaborate with partners in their works which have good impact on their performance.

Vincent (1998) explained that ISO 9001 is a standard - the international standard for quality system, which provides requirements and recommendations for the design, production steps and assessment and a management system. From such understanding can be concluded that ISO 9001 is a standard that plays an important role in the field of quality systems, especially which discusses the control of production steps or services in the scope of production or services.

Quality Management System (QMS) of SMKN 2 Jember is categorized as good system. The description of respondents evaluation based on each indicator variable quality management system that consists of a process approach, understanding the key competencies, total optimization, visionary leadership, approach to the facts, collaborate with partners, the involvement of the entire human resources (HR), the development of sustainable creation of value-added for 
learners. Based on Table 4.6 discovered that the means of the overall indicator in the variable declaration of the quality management system is perceived by the respondents is 4.09. The largest average contained in indicator of collaborating with partner is 4.28, while the smallest means indicator engagement contained in the whole of human resources is 3.98 . It indicates that most of the teachers at SMK 2 Jember are able to work with partners in achieving the goals of SMM.

The results are consistent with the results Fauziah (2015) which showed partially significant influence SMM on teacher performance.

Based on the results and a discussion of the influence of the Quality Management System (QMS), work culture and leadership on the performance of teachers at SMK Negeri 2 Jember, it was concluded to improve teacher performance can be improved in QMS. The conclusion of this hypothesis is QMS can be supported by the ability of teachers in the ability to collaborate with partners.

\section{IMPLICATIONS}

The implications of the findings of this study can contribute to this research supports the theory and research which states that: (1) Quality Management System (QMS) have a significant effect on the performance of teachers at SMK Negeri 2 Jember, (2) Recommendations for Head Master of SMKN 2 Jember in the form of: retaining the ability to collaborate with partners, and increasing the understanding of main key competencies such as understanding the process in the implementation of QMS.

The result of this research was largely to improve productive teachers' performance and the criteria of QMS should be increased. This result is consistent with the concept of human resources.

\section{REFERENCES}

Arif dan Farid. 2011. Pengaruh Kepemimpinan, Stres Kerja, Disiplin Kerja dan Kompensasi dengan Kinerja Pegawai. Jurnal Ekonomi Manajemen Sumber Daya. Vol. 12, No. 1, Juni 2011.

Baihaqi ,Muhammad Iqbal. 2015. Pengaruh Gaya Kepemimpinan Kepala Sekolah Dan Motivasi Kerja Terhadap Kinerja Guru Di Ma A'arif Selorejo Blitar. Jurnal Konstruktivisme, Vol. 7, No. 2, Juli 2015: FKIP Universitas IslamBalitar,Blitar

Dimyati, Mohamad. 2009. Analisis SEM dakam Uji Pengaruh Beberapa Variabel Terhadap Loyalitas, Kajian Berbasis Riset pada Debitur Kredit Usaha Kecil. Jakarta: Mitra Wacana Media.

Dharma, Agus. 2003. Manajemen Supervisi:Petunjuk Praktis Bagi Para Supervisor.

Edisi Revisi. Cetakan kelima. Jakarta: Raja Grafindo Persada.

Depdikbud. 2012. Buku Pedoman Pelaksanaan Penilaian Kinerja Guru. Jakarta.

Fauziah. 2014. Strategi Kepala Sekolah Melalui Kinerja Guru Melali penerapan ISO 9001:2008 di SMPN 5 Surabaya. (Surabaya: Preesindo)

Gering Supriyadi, 2003., Budaya Kerja Organisasi Pemerintah, Bahan Ajar Diklat Prajabatan Golongan I dan II, Lembaga Administrasi Negara.

Gering, Supriyadi dan Triguno. 2001. Budaya Kerja Organisasi 
Pemenrintah. Jakarta. Lembaga Administrasi Negara.

Hasibuan, Malayu SP. 2008. Manajemen

Sumber Daya Manusia. Jakarta: PT.

Bumi Aksara

Istianto, Bambang. 2011. Manajemen pemerintahan dalam perspektif pelayanan publik. Jakarta: Raja Grafindo Persada

Lathifah, Zahra Khusnul . Pengaruh Penilaian Kinerja Guru (PKG) dan Budaya Organisasi Terhadap Kinerja Guru di Sekolah Menengah Pertama Islam (SMPI) di Kecamatan Ciawi Bogor Jawa Barat.Tesis Program Pascasarjana. IAIN Surakarta.

Noor, Juliansyah. (2011). Metodologi Penelitian: Skripsi, Tesis, Disertasi, dan Karya Ilmiah. Jakarta: Kencana Prenada Media Group.

Ndraha, Talidziduhu. (2005). Teori Budaya Organisasi. Jakarta: Rineka Cipta.

Pramono, Harry.2012. Pengaruh Sistem Pembinaan, Sarana Prasarana Dan Pendidikan Latihan Terhadap Kompetensi Kinerja Guru Pendidikan Jasmani Sekolah Dasar Di Kota Semarang . Jurnal Penelitian Pendidikan Vol. 29 Nomor 1 tahun 2012. Fakultas Ilmu Keolahragaan, Universitas Negeri Semarang

Rivai Veithzal. 2008. Kepemimpinan dan Perikaku Organisasi. Edisi Kedua. Jakarta : PT. Raja Grafindo Persada.

Riyadi, Slamet. 2011. Pengaruh Kompensasi Finansial, Gaya Kepemimpinan, dan Motivasi Kerja Terhadap Kinerja Karyawan pada Perusahaan Manufaktur di Jawa Timur. Surabaya : Universitas 17 Agustus 1945

Sugiono. (2007). Metode Penelitian Kuantitatif, Kualitatif, fan $R \& D$. Bandung: Alfabeta.
Sedarmayanti,2008. Manajemen Sumber Daya Manusia, Reformasi Birokrasi dan Manajemen PNS. Bandung: PT. Refika Aditama.

Siagian,P.Sondang.2007.Mnajemen Sumber Daya Manusia. Cetakan ke 15.Jakarta: PT.Bumi Aksara

Sugiyono. 2012. Metode Penelitian Bisnis. Bandung:Alfabeta

Suryani, Susi. 2013.Pengaruh Budaya kerja Terhadap Kinerja Guru dalam Proses Belajar Mengajar Sekolah Menengah Atas Dan Kejuruan di Kecamatan Prambanan.Skripsi Program Studi Manajemen Pendidikan. UNY

Soetopo, Meita Pragiwani. 2016. Pengaruh kepemimpinan, pendidikan dan pelatihan Motivasi kerja, dan budaya organisasi Terhadap kompetensi dan kinerja guru. Jurnal STEI Ekonomi Volume 25 - Nomor 1, Juni 2016. Sekolah Tinggi Ilmu Ekonomi Indonesia

Suwardi, Rudi. Sistem Manajemen Mutu ISO 9001:2008. Penerapan Untuk Mencapai TQM. (Jakarta: Remaja Rosdakarya, 2003)

Sadar. 2015. Hubungan Persepsi Gaya Kepemimpinan Kepala Sekolah Dan Efikasi Diri Dengan Kinerja Guru.Tesis program magister psikologi sekolah pascasarjana : Universitas muhammadiyah Surakarta.

Suwartana, I Made. 2010. Kontribusi kualitas Penerapan Sistem Manajemen Mutu ISO 2001:2008 Terhadap penyelenggaraan peenddidikan di SMKN 3 Singaraja (Bali)

Sautro, Ervan Andi. (2012). Pengaruh Penerapan SMM ISO 9001:2008 dan Kepemimpinan Kepala Sekolah Terhadap Kinerja Guru.(Yogyakarta: presindo) 
Tabrani Rusyan dkk. (2000) Upaya Meningkatkan Budaya Kinerja Guru, Cianjur: CV. Dinamika Karya Cipta

Wursanto, Ig., (2002). Dasar-dasar Ilmu Organisasi. Yogyakarta: Andi Publisher
Yukl, Gary. 1998. Kepemimpinan dalam Organisasi Leadership

Organizations 3e. Jakarta:Prenhalindo

\section{BIOGRAPHY}

Agus Dedi Mustofa, S.Pd.T, MM was born 33 years ago, in Jember on August 16, 1984. He was born as the first child of Mr. and Mrs. Mustafa Jumaidah. Husband of Dian Narulita Tristina, S.Pd, MM, basic education to upper secondary education in Jember from SDN Jenggawah 2 graduated in 1997, SMPN 1 Jenggawah graduated in 2000, and SMKN 2 Jember graduated in 2003. The father of three children and then is studying in higher education studies Strata 1 (S1) in Yogyakarta State University (UNY) Faculty of Engineering and majored in Mechanical Engineering Education. He then devoted himself as a teacher of vocational school Mechanical Engineering at SMK 2 Jember and then went on to study Tertiary school (S2) in STIE MANDALA Jember majoring Master of Management (MM). 